\title{
Prospects of Citrus sinensis (masumbi) cultivation in Haryana State, India
}

\author{
Pawan Kumar*, P. S. Shehrawat, Anil Kumar Rohila and B. S. Ghanghas and Ashok Kumar ${ }^{1}$ \\ Department of Extension Education, CCS Haryana Agricultural University, Hisar-125 004 (Haryana), INDIA \\ ${ }^{1}$ Directorate Extension Education, CCS Haryana Agricultural University, Hisar-125 004 (Haryana), INDIA \\ *Corresponding author E-mail: pawanbhukal26@gmail.com
}

Received: August 22, 2015; Revised received: January 26, 2016; Accepted: May 16, 2016

\begin{abstract}
The empirical study on prospects of Citrus sinensis cultivation by farmers indicated that overall prospects of masumbi ( $C$. sinensis) crop were medium to high since $77.5 \%$ respondents belonged to these categories. Majority of respondents agreed that better market facilities (weighted mean score 2.72), increased purchasing power of people (2.65), better fruit quality (2.62), better economic return (2.53) and increase in demand of fruit were the major prospective aspects for its wider adoption (2.53), whereas better technical support (1.20) and better credit facilities (1.08) both were not up to the desired level as expressed by the farmers. So the government should make concerted efforts to further strengthen the highly prospective aspects like better marketing facilities, cultivars of better quality fruits at farm gate or village level. On the basis of result obtained, the prospects of masumbi (C. sinensis) cultivation may be high in future.
\end{abstract}

Keywords: Citrus sinensis, Cultivation, Fruit, Prospects

\section{INTRODUCTION}

India is the second largest producer of fruits after China, with a production of 88977 thousand million tonnes of fruits from an area of 7216 thousand hectares .Now a day's citrus has become a major commercial fruit crop in the Haryana state. Citrus has vigorous growth and heavy yield with favourable growing conditions in orchards and sufficient irrigation. According to 2014 statistics, in Haryana the citrus is grown on an area of 19.4 thousand ha with production 235.4 thousand MT (Anonymous, 2014).

Today fruits and vegetable farming as a diversified farming is important to generate employment round the year, supplement farm economy and to earn foreign exchange also by enhancing the export. As well as fruits play an important role in human nutrition offer diversity indirect, ecological sustainability and fight against hunger. It is generally stated that the living standard of people can be judged by the production as well as consumption of fruits.

Keeping in view the above facts and importance of this fruit towards for the country as a whole and Haryana (India) in particular, the study was conducted with the objective to find out the prospects of masumbi (C. sinensis) cultivationin Haryana state.

\section{MATERIALS AND METHODS}

To collect the primary data on prospects of Citrus sinensis cultivation perceived by farmers, the respondents were selected with multistage sampling. Among fruit growing states of India, Haryana was purposively selected being emerging state in Citrus cultivation as well as direct access to the investigators. From state, Bhiwani district was also selected purposively because it fall in Southern Haryana cluster of NHM scheme for development of citrus cultivation due to suitable climate and soil requirement along with maximum area under drip irrigation. Further 3 blocks viz. Dadri, Badhra and Loharu were selected purposively. From each block 40 farmers were selected randomly, making a total of 120 respondents. The data were selected with the help of well-structured and pre-tested interview schedule. The schedule consisted 11 items like better market facilities, better fruit quality, better economic returns etc. The responses were obtained on three-point continuum scale in case of prospects (More bright, somewhat bright and not at all bright) and scores were given as 3,2 and 1, respectively. After that frequency was multiplied with the score $(3,2$ or 1$)$ and total weighted score was obtained and total weighted score was divided by total respondents (120) for weighted mean score. In case of mean score which is expressed in percentage, total cumulative frequency was divided by total possible score. The data were analysed with frequency, weighted frequency, cumulative frequency, weighted mean score, mean score expressed and rank order.

\section{RESULTS AND DISCUSSION}

Overall prospects of $\boldsymbol{C}$. sinensis crop: During the present study result pertaining to overall prospects of C. sinensis crop presented in Table 1 clearly show that majority of farmers has medium (57.5\%) prospects 
level followed by $22.5 \%$ low level and only $20.0 \%$ to high level. In nutshell, $77.5 \%$ of the respondents had prospects of $C$. sinensis cultivation from medium to high level. Low level of prospects may be due to lack of better technical support regarding this crop. The study gets support from Negi (2011) who reported that prospects growth of apple production can be increase in Kinnaur district of Himachal Pradesh if modern technology, availability of high quality of seeds, proper management of labour, graders, packing and transport, marketing, better quality of pesticides, insecticides, fertilizers and proper irrigation facilities etc. are provided.

Prospects of $\boldsymbol{C}$. sinensis crop: Present study in Table 2 elaborates the result pertaining prospects of C. sinensis crop in which most of the farmers agreed 'better market facilities' with weighted mean score 2.72 giving $1^{\text {st }}$ rank, 'purchasing power of people is increasing' and 'better fruit quality' with weighted mean score 2.65 and 2.62 were ranked $2^{\text {nd }}$ and $3^{\text {rd }}$ followed by, 'better economic return' and 'demand is increasing' with weighted mean score 2.53 occupied $4^{\text {th }}$ rank. The prospects of 'Food habit of people is changing', 'high price of produce' as well as 'better input facilities' and 'better only for those who are residing near the city' with weighted mean score 2.52, $2.22,2.00$ and 1.47 were ranked $5^{\text {th }}, 6^{\text {th }}, 7^{\text {th }}$ and $8^{\text {th }}$ respectively. 'Better technical support' and 'better credit facilities are available' with weighted mean score 1.20 and 1.08 were ranked $9^{\text {th }}$ and $10^{\text {th }}$ respectively. Better market facilities in the region especially the local district market as well as sell along the road side followed by purchasing power of people and better fruit quality were highly prospective aspects of masumbi followed by better economic return and increasing demand were major aspects. The study gets

Table 1. Overall prospects of $C$. sinensis cultivation $(\mathrm{n}=120)$.

\begin{tabular}{lllll}
\hline S. N. & Category & Score Range & Frequency & Percentage \\
\hline 1 & Low & $17-21$ & 27 & 22.5 \\
2 & Medium & $22-26$ & 69 & 57.5 \\
3 & High & $27-31$ & 24 & 20.0 \\
\hline
\end{tabular}

Table 2. Prospects of $C$. Sinensis cultivation perceived by farmers $(n=120)$.

\begin{tabular}{|c|c|c|c|c|c|c|c|}
\hline $\begin{array}{l}\text { S. } \\
\text { N. }\end{array}$ & Items & Frequency & $\begin{array}{l}\text { Weighted } \\
\text { frequency }\end{array}$ & $\begin{array}{l}\text { Cumulative } \\
\text { frequency }\end{array}$ & $\begin{array}{l}\text { Mean } \\
\text { score }\end{array}$ & $\begin{array}{l}\text { Mean score ex- } \\
\text { pressed in } \%\end{array}$ & $\begin{array}{l}\text { Rank } \\
\text { order }\end{array}$ \\
\hline \multirow[t]{3}{*}{1} & \multirow{3}{*}{$\begin{array}{l}\text { Better market facilities } \\
\text { are available }\end{array}$} & 93 & 279 & 279 & \multirow[t]{3}{*}{2.72} & \multirow[t]{3}{*}{90.55} & \multirow[t]{3}{*}{$\mathrm{I}$} \\
\hline & & 20 & 40 & 319 & & & \\
\hline & & 07 & 07 & 326 & & & \\
\hline \multirow[t]{3}{*}{2} & \multirow{3}{*}{$\begin{array}{l}\text { Purchasing power of } \\
\text { people is increasing }\end{array}$} & 77 & 231 & 231 & \multirow[t]{3}{*}{2.65} & \multirow[t]{3}{*}{88.05} & \multirow[t]{3}{*}{ II } \\
\hline & & 43 & 86 & 317 & & & \\
\hline & & 00 & 00 & 317 & & & \\
\hline \multirow[t]{3}{*}{3} & \multirow[t]{3}{*}{ Better fruit quality } & 74 & 222 & 222 & \multirow[t]{3}{*}{2.62} & \multirow[t]{3}{*}{87.22} & \multirow[t]{3}{*}{ III } \\
\hline & & 46 & 92 & 314 & & & \\
\hline & & 00 & 00 & 314 & & & \\
\hline \multirow[t]{3}{*}{4} & Better economic & 67 & 201 & 201 & \multirow[t]{3}{*}{2.53} & \multirow[t]{3}{*}{84.44} & \multirow[t]{3}{*}{ IV } \\
\hline & \multirow[t]{2}{*}{ Returns } & 50 & 100 & 301 & & & \\
\hline & & 03 & 03 & 304 & & & \\
\hline \multirow[t]{3}{*}{5} & \multirow[t]{3}{*}{ Demand is increasing } & 66 & 198 & 198 & \multirow[t]{3}{*}{2.53} & \multirow[t]{3}{*}{84.44} & \multirow[t]{3}{*}{ IV } \\
\hline & & 52 & 104 & 302 & & & \\
\hline & & 02 & 02 & 304 & & & \\
\hline \multirow[t]{3}{*}{6} & \multirow{3}{*}{$\begin{array}{l}\text { Food habit of people is } \\
\text { changing }\end{array}$} & 63 & 189 & 189 & \multirow[t]{3}{*}{2.52} & 84.16 & V \\
\hline & & 57 & 114 & 303 & & & \\
\hline & & 00 & 00 & 303 & & & \\
\hline 7 & High price of produce & 29 & 87 & 87 & 2.22 & 74.16 & VI \\
\hline & & 89 & 178 & 265 & & & \\
\hline & & 02 & 02 & 267 & & & \\
\hline 8 & Better inputs facilities & 09 & 27 & 27 & 2.00 & 66.66 & VII \\
\hline & are available & 102 & 204 & 231 & & & \\
\hline & & 09 & 09 & 240 & & & \\
\hline 9 & Better for only those who & 16 & 48 & 48 & 1.47 & 48.88 & VIII \\
\hline & are residing near the city & 24 & 48 & 96 & & & \\
\hline & & 80 & 80 & 176 & & & \\
\hline 10 & Better technical & 01 & 03 & 03 & 1.20 & 40.00 & IX \\
\hline & support is available & 22 & 44 & 47 & & & \\
\hline & & 97 & 97 & 144 & & & \\
\hline 11 & Better credit facilities are & 01 & 03 & 03 & 1.08 & 36.11 & $X$ \\
\hline & available at present & 08 & 16 & 19 & & & \\
\hline & & 111 & 111 & 130 & & & \\
\hline
\end{tabular}


support from Rohila et al. (2014) who reported that prospects of direct seeded rice in Haryana state such as better quality of produce and better economic return play an important role to motivate and adoption. Present study also shows that food habit of people is changing, high price of produce, better input facilities and better only for those who are residing near the city were medium level of prospects. According to present study better technical support and better credit facilities are available has low level of prospects which may be due to lack of timely technical information related to insect-pest/diseases etc. Credit facilities play an important role in adoption of any technology. If farmers faced financial problem then new technology would not be adopted. Technical support and credit facility is mainly responsible for low level of adoption of technology intensive as well capital intensive technology at farmer field. Findings are in agreement with the study of Choudhary and Bangarwa (2013) which concluded that the most perceived constraints in Kinnow production by the farmers of Sri-Ganganagar district of Rajasthan was high initial cost in establishing of orchard and Singh (2004) who reported that inadequate training for technical skills is major constraint in mango production.

\section{Conclusion}

The present study concluded that overall prospects of masumbi (Citrus sinensis) cultivationweremedium to high level. Vast majority of farmers agreed with better market facilities and increasing purchasing power of people, whereas better economic return, demand is increasing, food habit of people is changing and high price of produce were perceived medium level prospects. Study also revealed that better technical support and better credit facilities both were ranked low level of prospects due to improper and inefficient functioning of institutions at village level. The government should address the problem of better technical support and credit facilities for wider adoption this fruit crop as perceived remunerative as well as increasing demand of fruit which ensure the food nutrition security in the region being most feasible fruit for diversification.

\section{REFERENCES}

Anonymous (2014). National Horticulture Database 2013 14, National Horticulture Board, Ministry of Agriculture, Govt. of India, Gurgaon

Choudhary, H.D. and Bangarwa, G.S. (2013). Knowledge and constraints in recommended kinnow production technology among the kinnow growers. International Journal of Agricultural Sciences. 9(2): 472-275.

Negi, P.P. (2011). A survey of growth prospects of apple production in Kinnaur district of Himachal Pradesh. Directorate of Horticulture, Kinnaur, Himachal Pradesh.

Singh, M. (2004). Adoption and constraints in mango cultivation. M.Sc.Thesis (unpublished) Department of Ext. Edu., CCSHAU, Hisar.

Rohila, A.K., Ghanghas, B.S. and Shehrawat, P.S. (2014). Prospects of Direct Seeded Rice Cultivation Technology in Haryana. Journal of Community Mobilization and Sustainable development. 9(2): 206-209. 